\title{
PRODUCTION AND PARTIAL CHARACTERIZATION OF FIBRINOLYTIC ENZYME FROM A SOIL ISOLATE ASPERGILLUS CARBONARIUS S-CSR-0007
}

\author{
AFINI A. V. M., SOORAJ S. NATH, SMITHA K. V., KUNHI A. A. M.
}

SIAS-Centre for Scientific Research (SIAS-CSR), SAFI Institute of Advanced Study, Rasiya Nagar, Vazhayoor East P. 0., 673633, (Via.)

Ramanattukara, Malappuram Dist., Kerala State, India

Email: soorajsn85@gmail.com

Received: 06 Sep 2016 Revised and Accepted: 050 0ct 2016

\begin{abstract}
Objective: This work was undertaken with the aim of isolating and screening fungal soil isolates with fibrinolytic activity.

Methods: Soil sample near slaughter house was collected and screened for fibrinolytic activity by using fibrin-agar. Enzyme production was optimized under various parameters like $\mathrm{pH}$, temperature, substrate concentration and purified partially by ammonium sulphate precipitation. The stability of the partially purified enzyme was analyzed under the influence of a wide range of $\mathrm{pH}$, temperature, and substrate concentrations.

Results: Among the seven isolates screened, Aspergillus carbonarius S-CSR-0007 exhibited largest clear zone and was selected for further studies. Among the various substrates tested casein was found to support the highest caseinolytic activity of $816 \mathrm{U} / \mathrm{ml}$ and fibrinolytic activity of $510 \mathrm{U} / \mathrm{ml}$. The culture supernatant of $A$. carbonarius S-CSR-0007 was fractionated by ammonium sulfate precipitation followed by dialysis, and maximum activity was obtained in the fraction with $80 \%$ ammonium sulfate, with an enzyme activity of $1200 \mathrm{U} / \mathrm{ml}$ using tyrosine as standard. The partially purified fibrinolytic enzyme showed optimal activity at $45^{\circ} \mathrm{C}$ and $\mathrm{pH} 7.0$. The enzyme was stable up to a temperature of $50{ }^{\circ} \mathrm{C}$ and $\mathrm{pH} 8.0$, and the optimum substrate concentration was $4 \%$.
\end{abstract}

Conclusion: The crude enzyme showed high blood clot lysis activity, which may be a good candidate in the pharmaceutical industry. However, more studies need to be carried out to establish its clinical use.

Keywords: Ammonium sulphate precipitation, Aspergillus carbonarius S-CSR-0007, Fibrin, Fibrinolytic enzyme

(C) 2016 The Authors. Published by Innovare Academic Sciences Pvt Ltd. This is an open access article under the CC BY license (http://creativecommons.org/licenses/by/4. 0/) DOI: http://dx.doi.org/10.22159/ijpps.2016v8i12.15069

\section{INTRODUCTION}

The fibrinolytic enzyme is a well-known subclass of proteinases which has an ability to degrade protein [1]. Fibrin is the main component of a blood clot, and it is normally formed from fibrinogen by the action of thrombin (E. C.21.5). Intravascular thrombosis, the accumulation of fibrin in blood vessels or in a chamber of heart, easily causes myocardial infarction and other cardiovascular diseases (CVD), resulted in 17 million deaths every year as per the report of World Health Organization (WHO) [2]. Disorders of blood clotting and fibrinolysis are serious medical problems leading to cerebral and myocardial infarction [3]. Many blood clot-dissolving agents, such as urokinase, streptokinase, and tissue plasminogen activator (t-PA), have been utilized in clinical treatments for CVD which activate plasminogen into active plasmin to degrade fibrin and plasmin-like proteins which directly degrade fibrin thereby dislodging thrombin rapidly and completely. Although these agents are used widely today, their expensive prices and undesirable side effects, prompt researchers to search for cheaper and safer resources; the number of proteases that can interfere with blood clotting have been purified and characterized from various sources including microorganisms. Microbial fibrinolytic enzymes are classified into three types: serine protease, metalloprotease and mixture of both serine and metalloprotease [4]. Major protein component of a blood clot, fibrin is formed from fibrinogen via proteolysis by thrombin. Fibrin clots can be hydrolysed by plasmin to avoid thrombosis in a blood vessel.

Fibrinolysis is of two types; primary fibrinolysis, is a normal body process and secondary fibrinolysis, is the breakdown of clots due to medicine, a medical disorder or some other cause. In fibrinolysis, the product of coagulation is broken down [5]. Plasmin cuts the fibrin mesh leading to the production of fragments and are cleaved by other proteases or by the kidney and liver. Plasminogen has an affinity to clot so it is incorporated to it when formed, but cannot cleave fibrin. Tissue plasminogen activator is released into the body very slowly by the damaged endothelium of blood vessels, such as after bleeding stopped, the clot broken down by the plasminogen which is trapped within the clot. Tissue plasminogen activator also inhibited by plasminogen activator inhibitor 1 and plasminogen activator inhibitor 2 , further, plasmin generation by producing active forms of t-PA and urokinase. When plasmin breaks down fibrin, fibrin degradation products (soluble parts) are produced, compete with thrombin, slow down clot formation by preventing fibrinogen to fibrin conversion. This can be seen in TCT (clotting time test), which is prolonged in person that has active fibrinolysis.

Although fibrinolytic enzymes are produced by many bacteria, earthworms, and snake toxin, but there have been few productions of the fibrinolytic enzyme from fungi [6]. In the present study, an attempt was made for the isolation, production and partial purification of the fibrinolytic enzyme from Aspergillus carbonarius S-CSR-0007 isolated from soil samples near slaughter house.

\section{MATERIALS AND METHODS}

The media used in this study were obtained from HiMedia Laboratories, India and chemicals used were of analytical grade.

Instruments used for the study

Orbital shaking incubator (Remi Elektrotechnik Limited, India), UVVis spectrophotometer (Thermo Scientific Evolution 201), electronic balance (Shimadzu AY220).

\section{Isolation and cultivation of fungal isolates}

Soil samples were collected from various locations near slaughter house. Samples were collected by scraping off the soil surface, and $10 \mathrm{~g}$ of soil were obtained from a depth of $2-5 \mathrm{~cm}$. Fungi present in the soil was isolated by serial dilution and spread plated on Sabouraud Dextrose agar (SDA) medium with $50 \mathrm{ppm}$ of tetracycline and incubated at room temperature for five days.

After five days, observed for the colonies in the incubated plates. The fungal colonies were subcultured to freshly prepared SDA and PIA 
with tetracycline (50 ppm) plates for the purification of colonies grown. The subcultured plates were incubated at room temperature for $28-72 \mathrm{~h}$.

For the further confirmation of microorganisms, the fungal cultures were stocked on SDA and PIA slants. The fungal spores were inoculated to fresh plates by using $0.1 \%$ tween 80 solutions in sterile distilled water. The fungal plates were spread with $0.1 \%$ tween 80 solution and spores were dislodged by using a sterile glass rod. The spore suspension was inoculated to SDA and PIA plates with tetracycline $(50 \mathrm{ppm})$.

\section{Preparation of blood clots for nitrogen source}

Buffalo blood was collected from slaughterhouse. The blood was allowed to clot for overnight at room temperature. Then the clots were shredded by using a surgical blade and placed in $1 \mathrm{~L}$ of distilled water in a beaker. The beaker was placed on the magnetic stirrer for further shredding and RBC removal. Water was replaced every half an hour. Repeated this procedure until the clot became grey in color. This clot was ground into fine powder by using mortar and pestle and dehydrated by using acetone. This powder was used as a source of fibrin and stored at $4{ }^{\circ} \mathrm{C}$.

\section{Screening of fibrinolytic organism}

The isolated organisms were spot inoculated on minimal medium containing powdered fibrin. The plates were incubated at room temperature for three days. Fibrinolytic organisms were showed a clear hallow around the colony, and the organism produced large zone was selected for further studies. The fungi with fibrinolytic activity were stock cultured on SDA slant with tetracycline $(50 \mathrm{ppm})$ at $4{ }^{\circ} \mathrm{C}$.

\section{Identification of organism}

The fungal species grown in the media were identified macroscopically and microscopically by using staining methods like saline wet mounting and LPCB (Lacto Phenol Cotton Blue) staining.

\section{Determination of caseinolytic activity}

This method was used to detect the proteolytic activity of the organism. Casein agar was prepared by using $1 \%$ casein. The organisms were spot inoculated on the medium and incubated at room temperature for $3 \mathrm{~d}$. Observed the colonies, proteolytic organisms showed clear hallow around the colony, indicating casein hydrolysed by the organism.

\section{Production of fibrinolytic enzyme}

Modified Czapekdox medium was used, consisting of the following ingredients (g/l) 5 casein, 5 sucrose, $30 \mathrm{KH}_{2} \mathrm{PO}_{4}, 1.0 \mathrm{MgSO}_{4} .7 \mathrm{H}_{2} \mathrm{O}$, $0.5 \mathrm{KCl}$ and $0.5 \mathrm{FeSO}_{4} .7 \mathrm{H}_{2} \mathrm{O}$; all ingredients were dissolved in 1,000 $\mathrm{ml}$ distilled water. Two different substrates casein and fibrin $(0.25 \%)$ were added to the Czapekdox medium. $50 \mathrm{ml}$ of the media were transferred to $250 \mathrm{ml}$ conical flask and sterilized by autoclaving at $121{ }^{\circ} \mathrm{C}$ for $20 \mathrm{~min}$ and cooled to room temperature. One $\mathrm{ml}$ of uniformly prepared spore suspension $\left(10^{5}\right.$ spores $\left.\mathrm{ml}^{-1}\right)$ from $7 \mathrm{~d}$ old cultures was used as inoculums (Aspergillus carbonarius). Inoculated medium was incubated at $37{ }^{\circ} \mathrm{C}$ in orbital shaker for $48 \mathrm{~h}$ at $100 \mathrm{rpm}$.

\section{Extraction of fibrinolytic enzyme}

After $5 \mathrm{~d}$, the content of the flasks was filtered through Whatman No.1 filter paper. Culture filtrates were centrifuged at 5,000 rpm for $10 \mathrm{~min}$ and the supernatant was used as the crude enzyme.

\section{Enzyme assay}

The reaction mixture containing $2.0 \mathrm{ml}$ of $0.5 \%$ casein solution in 0.1 $\mathrm{ml}$ of carbonate buffer ( $\mathrm{pH} 9.3$ ) and $0.1 \mathrm{ml}$ of enzyme solution in the total volume of $2.1 \mathrm{ml}$ [10]. Then the reaction mixture was assayed [7]. Absorbance was taken at $660 \mathrm{~nm}$ in UV spectrophotometer.

\section{Optimization of cultural conditions}

For the fibrinolytic enzyme production, three factors were selected; they are substrate concentration, $\mathrm{pH}$ and temperature. The effect of three factors on fibrinolytic enzyme production was experimented [8].

\section{Effect of substrate concentration on enzyme production}

To study the effect of substrate concentration on enzyme production, $1 \mathrm{ml}$ of uniformly prepared spore suspension $\left(10^{5}\right.$ spores $\mathrm{ml}^{-1}$ ) from $7 \mathrm{~d}$ old cultures was used as inoculum and incubated at different substrate concentrations such as $1 \%$ to $4 \%$. Inoculated medium was incubated at $37^{\circ} \mathrm{C}$ in orbital shaker for $48 \mathrm{~h}$ at $100 \mathrm{rpm}$ and then estimated its enzyme activity.

\section{Effect of $\mathrm{pH}$ on enzyme production}

The production medium was adjusted at different $\mathrm{pH}$ levels such as $\mathrm{pH} 4.0$ to 9.0 using 0.2 molar with specific buffer solutions. One $\mathrm{ml}$ of uniformly prepared spore suspension $\left(10^{5}\right.$ spores $\left.\mathrm{ml}^{-1}\right)$ from $7 \mathrm{~d}$ old cultures was used as inoculums. Inoculated medium was incubated at $37^{\circ} \mathrm{C}$ in orbital shaker for $48 \mathrm{~h}$ at $100 \mathrm{rpm}$ and then estimated its enzyme activity.

\section{Effect of temperature on enzyme production}

To study the effect of incubation temperature for maximum fibrinolytic enzyme production, solution was incubated at different temperatures such as $20^{\circ} \mathrm{C}$ to $60^{\circ} \mathrm{C}$. One $\mathrm{ml}$ of uniformly prepared spore suspension $\left(10^{5}\right.$ spores $\left.\mathrm{ml}^{-1}\right)$ from $7 \mathrm{~d}$ old cultures was used as inoculums. Inoculated medium was incubated at $37{ }^{\circ} \mathrm{C}$ in orbital shaker for $48 \mathrm{~h}$ at $100 \mathrm{rpm}$ and then estimated its enzyme activity.

\section{Protein estimation}

Quantitative estimation of the protein content of individual fraction obtained after different steps was done [7].

\section{Partial purification by ammonium sulphate precipitation method}

The crude enzyme $(100 \mathrm{ml})$ was placed in a salt-ice bath. Ammonium sulphate was added for saturation, at varying concentration of $20 \%$, $40 \%, 60 \%, 80 \%$ and $100 \%$ with a constant stirring ice bath for $1 \mathrm{~h}$. Precipitated protein was removed by centrifugation at $1,000 \mathrm{rpm}$ for $20 \mathrm{~min}$ at $4{ }^{\circ} \mathrm{C}$. Then the supernatant was discarded [9]. The precipitated protein was dissolved in $50 \mathrm{mmol}$ Tris- $\mathrm{HCl}(10 \mathrm{ml}), \mathrm{pH}$ 7.0, assayed for determining enzyme activity and protein content [7].

\section{Dialysis of the partially purified enzyme}

Dialysis bag $(8 \mathrm{~cm})$ was cut and placed in $100 \mathrm{ml}$ of $2 \%(\mathrm{w} / \mathrm{v})$ sodium bicarbonate and 1 mmol EDTA was added to chelate any metal ions. It was boiled for $10 \mathrm{~min}$ and washed with boiling distilled water for $10 \mathrm{~min}$. The boiling process was repeated with distilled water again. The activated dialysis bag was filled with the enzymes and sealed from the both sides without any air bubbles using dialysis bag closure clips. The bag was kept in $500 \mathrm{ml}$ of 50 mmol Tris- $\mathrm{HCl}, \mathrm{pH} 7.0$ solution on a magnetic stirrer in ice cold condition for $8 \mathrm{~h}$. The buffer was frequently changed at an interval of one hour to avoid equilibration [10].

\section{Characterization of the partially purified enzyme}

\section{Effect of temperature}

The enzyme was assayed in the reaction mixture containing $2.0 \mathrm{ml}$ of $0.5 \%$ casein solution in $0.1 \mathrm{M}$ carbonate buffer $(\mathrm{pH} 4.0)$ and $0.1 \mathrm{ml}$ of enzyme solution in the total volume of $2.1 \mathrm{ml}$. After incubation at $20{ }^{\circ} \mathrm{C}, 25^{\circ} \mathrm{C}, 30^{\circ} \mathrm{C}, 35^{\circ} \mathrm{C}, 40{ }^{\circ} \mathrm{C}, 45^{\circ} \mathrm{C}, 50{ }^{\circ} \mathrm{C}, 55^{\circ} \mathrm{C}, 60{ }^{\circ} \mathrm{C}$ and $65^{\circ} \mathrm{C}$ for $5 \mathrm{~min}$, the reaction was stopped by adding $3.0 \mathrm{ml}$ of $10 \%$ ice cold TCA solution [10]. The reaction mixture was filtered by using Whatman No 1 filter paper and the enzyme activity was assayed [7].

\section{Effect of substrate concentration}

The enzyme was assayed in the reaction mixture containing $2.0 \mathrm{ml}$ of different concentration of $0.25 \%, 0.5 \%, 1 \%, 2 \%, 3 \%$ and $4 \%$ casein solution in $0.1 \mathrm{M}$ carbonate buffer $(\mathrm{pH} 4.0)$ and $0.1 \mathrm{ml}$ of enzyme solution in the total volume of $2.1 \mathrm{ml}$. After incubation at 37 ${ }^{\circ} \mathrm{C}$ for $5 \mathrm{~min}$ the reaction was stopped by adding $3 \mathrm{ml}(10 \%)$ of ice cold TCA [10]. The reaction mixture was filtered by using Whatman No 1 filter paper and enzyme activity was measured [7].

\section{Effect of $\mathbf{p H}$}

Buffer with different pH of 4.5 to 9.5 was prepared [11]. Reaction buffer $(2 \mathrm{ml})$ with different $\mathrm{pH}$ was taken in a test tube, and $0.1 \mathrm{ml}$ of 
enzyme sample was added. The samples were incubated at $37^{\circ} \mathrm{C}$ for $5 \mathrm{~min}$. After incubation, the reaction was stopped by adding $3 \mathrm{ml}$ (10\%) of ice cold TCA [10]. The reaction mixture was filtered, and enzyme activity was measured [7].

\section{Determination of enzyme stability}

Enzyme stability was determined to find out at what conditions the enzyme can be stored by maintaining its maximum activity and stability [11].

\section{Enzyme stability at different temperature}

Supernatant $(0.5 \mathrm{ml})$ was added into different test tubes. Each tube was incubated at different temperatures $(20,25,30,35,40,45,50,55,60$ and $65^{\circ} \mathrm{C}$ ) $0.5 \mathrm{ml}$ of carbonate buffer with $0.5 \%$ casein of $\mathrm{pH} 4.0$ was added into each test tube and incubated at $37^{\circ} \mathrm{C}$ for $10 \mathrm{~min}$. After incubation the reaction was stopped by adding $3 \mathrm{ml}(10 \%)$ of ice-cold TCA. The reaction mixture was filtered and enzyme activity was measured [7].

\section{Enzyme stability at different $\mathrm{pH}$}

Supernatant $(0.5 \mathrm{ml})$ was mixed with $0.5 \mathrm{ml}$ of 0.1 molar buffers at different $\mathrm{pH}$ ranges in different test tubes (pH: 2.5, 3.0, 3.5, 4.0, 4.5, $5.0,5.5,6.0,6.5,7.0,7.5,8.0,8.5,9.0,9.5,10.0$ and 10.5) and incubated at $37{ }^{\circ} \mathrm{C}$ for $10 \mathrm{~min}$. After incubation, the reaction was stopped by adding $3 \mathrm{ml}(10 \%)$ of ice-cold TCA. The reaction mixture was filtered, and enzyme activity was measured [7].

\section{In vitro activity of fibrinolytic enzymes}

For the determination of fibrinolytic activity of produced enzyme, $5 \mathrm{ml}$ of buffalo blood was collected from the slaughterhouse. The collected blood was filled into the capillary tube and kept at room temperature for $45 \mathrm{~min}$. Blood clots were formed inside the capillary tube, and the tube was cut at length of $5 \mathrm{~mm}$. Pieces of capillary tube were placed in petridish and enzyme extract was added to it; kept at room temperature for $15 \mathrm{~min}$. After $15 \mathrm{~min}$, the lysis of clot inside the capillary tube by the fibrinolytic activity of enzyme extract was observed.

\section{RESULTS}

\section{Isolation and identification of fungal isolates}

Fibrinolytic fungi from soil samples were collected from various locations near slaughter house. The fungal isolates grown on SDA and PIA plates with $50 \mathrm{ppm}$ of tetracycline were identified macroscopically and microscopically by using staining methods like saline wet mounting and LPCB (Lacto Phenol Cotton Blue) staining. Seven fungal isolates were identified as Aspergillus niger, Aspergillus fumigatus, Aspergillus carbonarius, Aspergillus flavus, Mucor sp., Penicillium sp. and Rhizopus sp.

\section{Screening of fibrinolytic fungi}

Fibrin plate agar showed clear zone around the spotted fungi (fig. 1) indicates the fibrinolytic activity, were used for further studies. Samples could be collected from dump yards of beef, fish and milk centers and fibrinolytic activity of organism was determined by using fibrin plate agar [12].

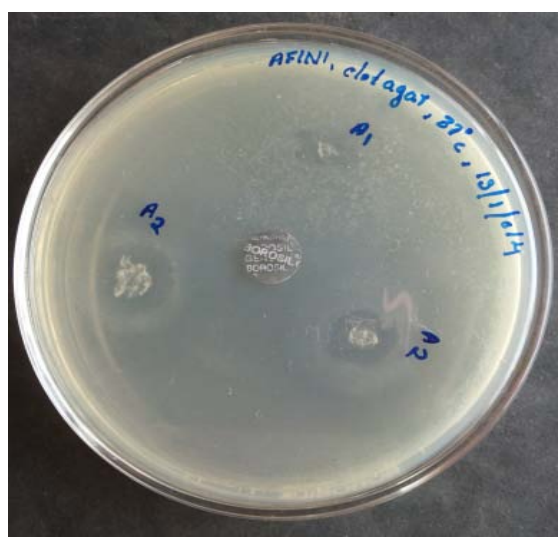

Fig. 1: Fungal isolates were grown on fibrin-agar

\section{Identification of fibrinolytic fungi}

Aspergillus carbonarius (fig. 2) from soil samples were collected from various locations near slaughter house. The fungal isolates grown on SDA and PIA plates with $50 \mathrm{ppm}$ of tetracycline were identified macroscopically and microscopically by using staining methods like saline wet mounting and LPCB (Lacto Phenol Cotton Blue) staining.

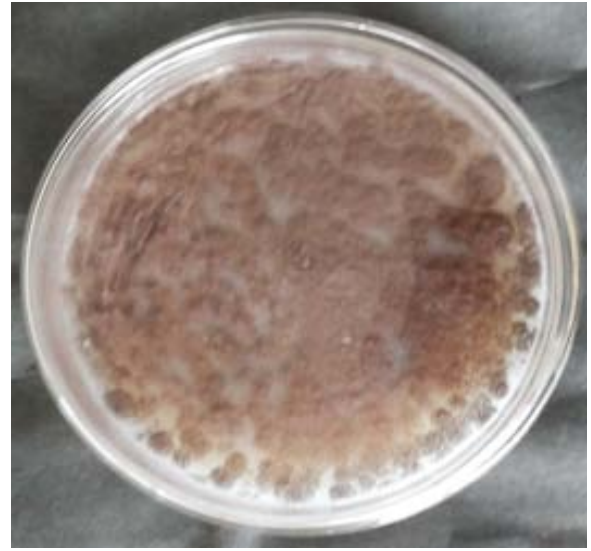

Fig. 2: Growth of Aspergillus carbonarius S-CSR-0007 on SDA

A new strain of the Aspergillus carbonarius S-CSR-0007 was isolated from the soil sample showed fibrinolytic activity towards fibrin as substrate.

\section{Determination of caseinolytic activity}

The isolated sample was tested to break down casein. On casein agar the isolated organism Aspergillus carbonarius S-CSR-0007 showed clear zone around the colony that means the organism hydrolyzes casein (fig. 3).

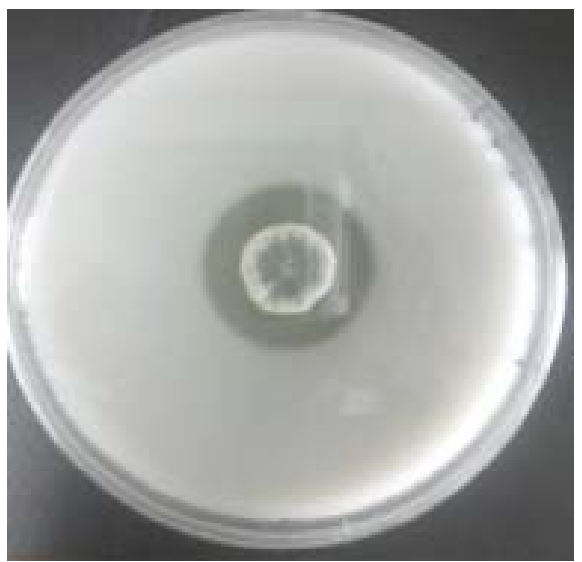

Fig. 3: Aspergillus carbonarius S-CSR-0007 on Casein agar

\section{Production and extraction of fibrinolytic enzyme}

Aspergillus carbonarius S-CSR-0007 was used for the enzyme production.

\section{Submerged fermentation using different growth substrate}

Two different growth substrates, casein, and fibrin $(0.25 \%)$ were used for the production of the enzyme, in which the growth substrate casein was given maximum enzyme production (table 1).

So casein was used as a growth substrate for further studies. 
Table 1: Effect of growth substrate on enzyme production

\begin{tabular}{lll}
\hline S. No. & Substrate & Enzyme activity (U/ml) \\
\hline 1 & Casein & 816 \\
2 & Fibrin & 459 \\
\hline
\end{tabular}

The ability of the crude enzyme of Aspergillus carbonarius S-CSR-0007 to digest different growth substrates was studied using fibrin and casein $(0.25 \%)$. BSA was used as the standard. Results indicated that at $10 \mathrm{~min}$ incubation the crude enzyme was able to digest the protein substrates were tested. Casein was rapidly digested to give $816 \mathrm{U} / \mathrm{ml}$ tyrosine compared to fibrin which gave $459 \mathrm{U} / \mathrm{ml}$ of tyrosine.

\section{Enzyme assay}

The activity of enzyme achieved was about $510 \mathrm{U} / \mathrm{ml}$ when compared to tyrosine.

\section{Protein estimation}

Protein content was estimated using BSA as standard [7] and the amount of protein present is $10 \mathrm{mg} / \mathrm{ml}$.

\section{Optimization of cultural conditions}

Effect of three factors on fibrinolytic enzyme production by Aspergillus carbonarius S-CSR-0007 experimented, and the results are shown in (fig. 4, 5 and 6). Optimum $\mathrm{pH}$, temperature and substrate concentration for maximum enzyme production was found to be $5.0,40^{\circ} \mathrm{C}$ and $3.5 \%$ respectively.

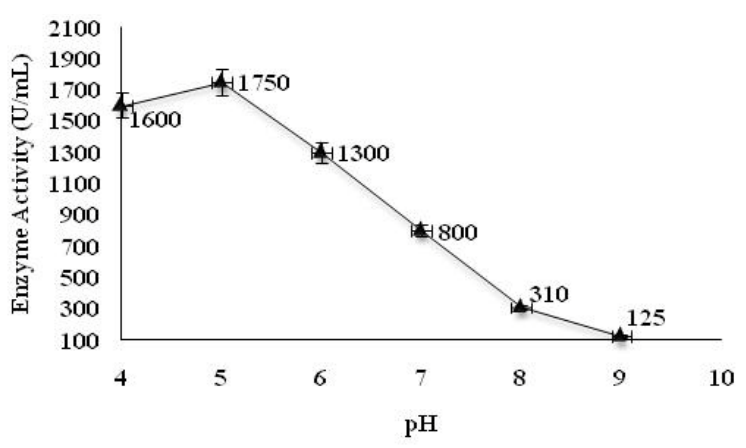

Fig. 4: Effect of $\mathrm{pH}$ on enzyme production $\mathrm{n}=6$

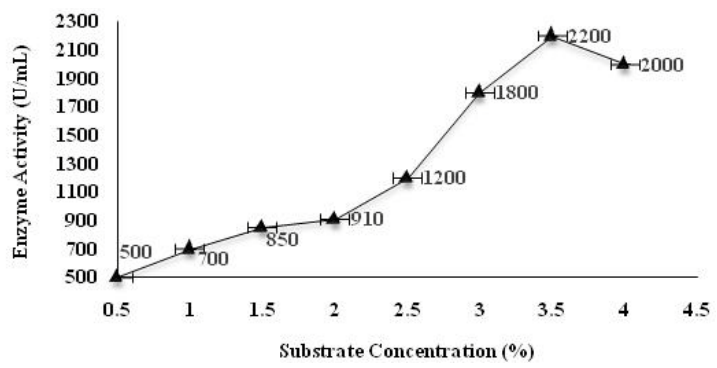

Fig. 5: Effect of substrate concentration on enzyme production n=8

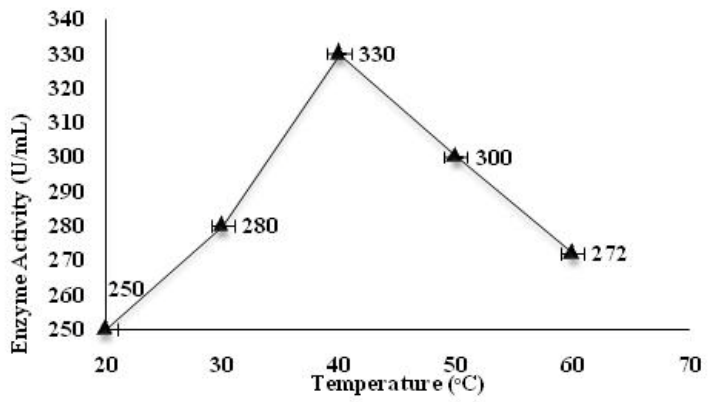

Fig. 6: Effect of temperature on enzyme production $n=5$
The result showed that the production of the enzyme is at $\mathrm{pH} 4.0$ to 6.0 with an optimum enzyme activity of $1750 \mathrm{U} / \mathrm{ml}$ at $\mathrm{pH} 5.0$, there was a decrease in $\mathrm{pH}$ values at higher values. The optimum temperature and substrate concentration for the enzyme production was at $40{ }^{\circ} \mathrm{C}$ with an enzyme activity of $330 \mathrm{U} / \mathrm{ml}$, and 3.5 with an enzyme activity of $2200 \mathrm{U} / \mathrm{ml}$ respectively.

\section{Partial purification of fibrinolytic enzyme}

\section{Ammonium sulphate precipitation method followed by dialysis}

The culture supernatant of Aspergillus carbonarius S-CSR0007 containing an initial enzyme activity of $510 \mathrm{U} / \mathrm{ml}$ was concentrated by varying concentrations of ammonium sulphate precipitation followed by dialysis. Varying concentrations of ammonium sulphate precipitation screening was carried out to determine the best percentage of ammonium sulphate saturation which gave the highest fibrinolytic activity [13]. The result for ammonium sulphate saturation on the precipitation of fibrinolytic enzyme from Aspergillus carbonarius S-CSR-0007 was shown in fig. 7. The optimum ammonium sulphate saturation was at $80 \%$ with an enzyme activity of $1,200 \mathrm{U} / \mathrm{ml}$.

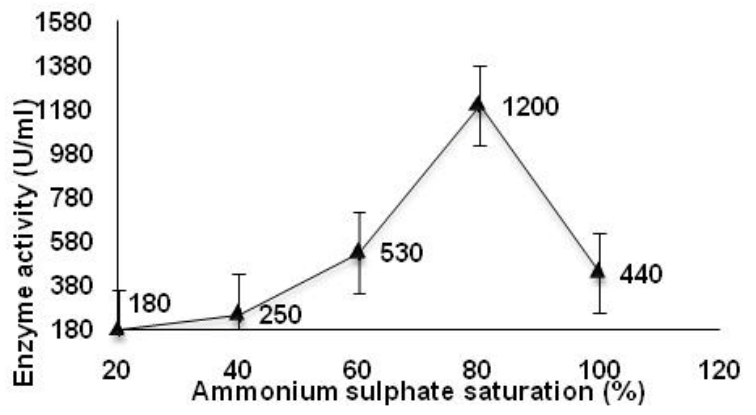

Fig. 7: Enzyme activity at different concentrations of ammonium sulphate $n=5$

\section{Characterization of the partially purified enzyme}

\section{Effect of temperature on enzyme activity}

The activity of the partially purified enzyme was determined at various temperatures ranging from $20^{\circ} \mathrm{C}$ to $55^{\circ} \mathrm{C}$. From the results (fig. 8), it showed that at $45^{\circ} \mathrm{C}$ enzyme production was maximum with the enzyme activity of $2091 \mathrm{U} / \mathrm{ml}$.

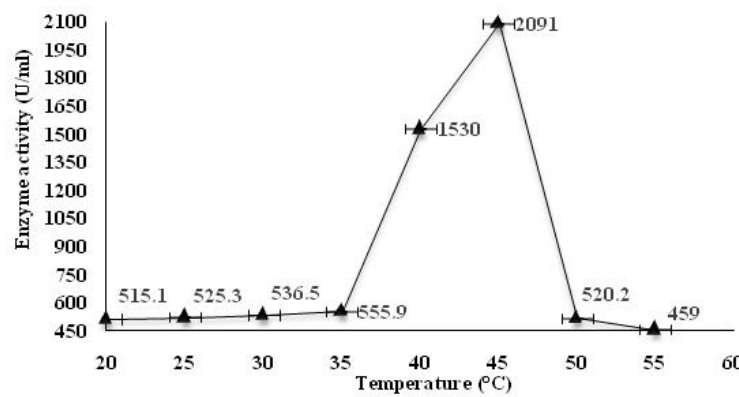

Fig. 8: Effect of temperature on enzyme activity $n=8$ 


\section{Effect of substrate concentration on enzyme activity}

Different concentrations of substrates were applied to investigate their effect on enzyme production. The result (fig. 9) shows that the enzyme activity increases with increase in substrate concentration. The maximum fibrinolytic activity showed at $4 \%$ substrate concentration was $1224 \mathrm{U} / \mathrm{ml}$

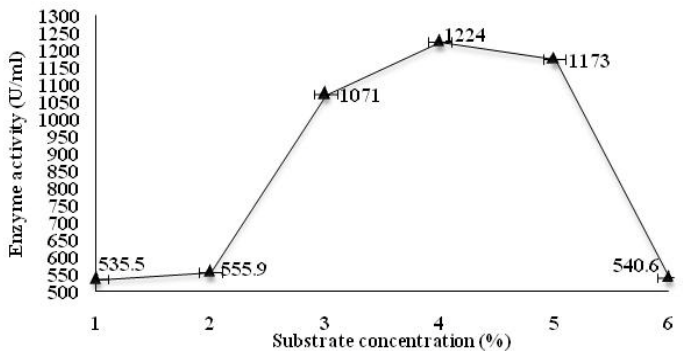

Fig. 9: Effect of substrate concentration on enzyme activity $n=6$

\section{Effect of pH on enzyme activity}

The influence of $\mathrm{pH}$ on the activity of the partially purified enzyme was determined using buffers at various $\mathrm{pH}$ values. The result (fig. 10 ) indicates that enzyme shows its highest enzyme activity 1130 $\mathrm{U} / \mathrm{ml}$ at $\mathrm{pH}$ 7.0. The enzyme activity increases with increase in $\mathrm{pH}$ till 7.0, above that the enzyme activity decreases gradually.

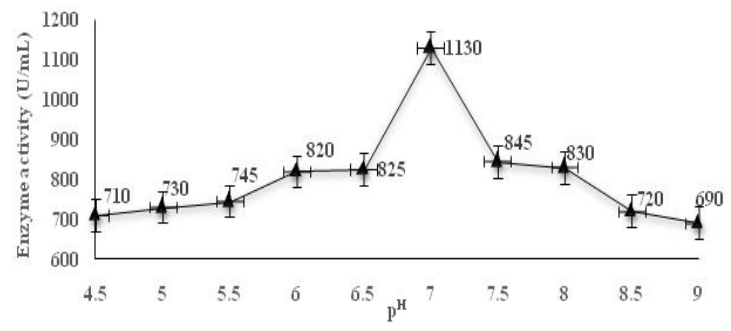

Fig. 10: Effect of $\mathrm{pH}$ on enzyme activity $\mathrm{n}=10$

\section{Enzyme stability}

Enzyme stability was determined to find out at what conditions the enzyme can be stored by maintaining its maximum activity. At this condition, the enzyme remains most stable.

\section{Effect of temperature on enzyme stability}

Enzyme stability was determined to find out at what conditions the enzyme can be stored by maintaining its maximum activity. At these

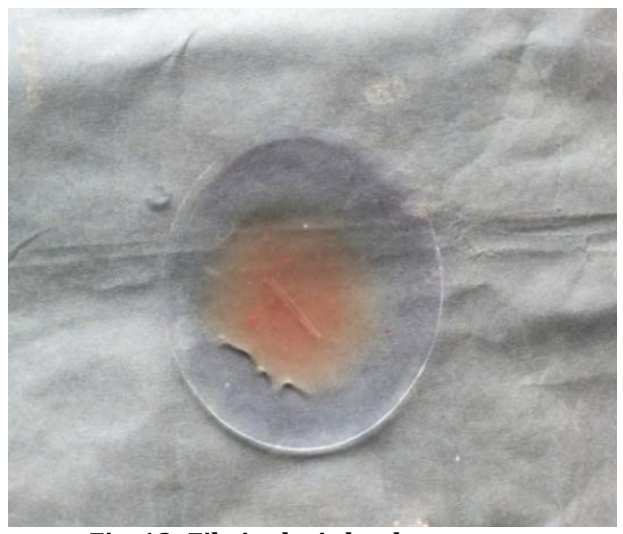

Fig. 13: Fibrinolysis by the enzyme conditions, the enzyme remains most stable. The thermal stability of the enzyme was measured for $10 \mathrm{~min}$ at $\mathrm{pH} 4.0$. The enzyme was stable in the temperature range of $40-50{ }^{\circ} \mathrm{C}$ and rapid decrease in activity was observed at a temperature above $50{ }^{\circ} \mathrm{C}$ (fig. 11).

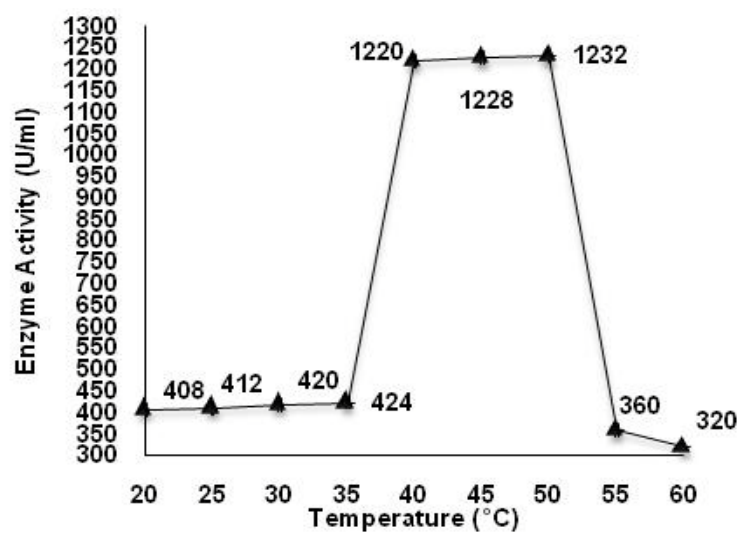

Fig. 11: Effect of temperature on enzyme stability $n=9$

\section{Effect of pH on enzyme stability}

The effect of $\mathrm{pH}$ on the enzyme stability of the enzyme was determined using buffers at various $\mathrm{pH}$ values. A fibrinolytic enzyme produced by Aspergillus carbonarius S-CSR-0007 was stable over a broad $\mathrm{pH}$ range of 6.0-9.0 with a maximum stability at $\mathrm{pH} 8.0$ (fig. 12) at temperature $37^{\circ} \mathrm{C}$ for $20 \mathrm{~min}$.

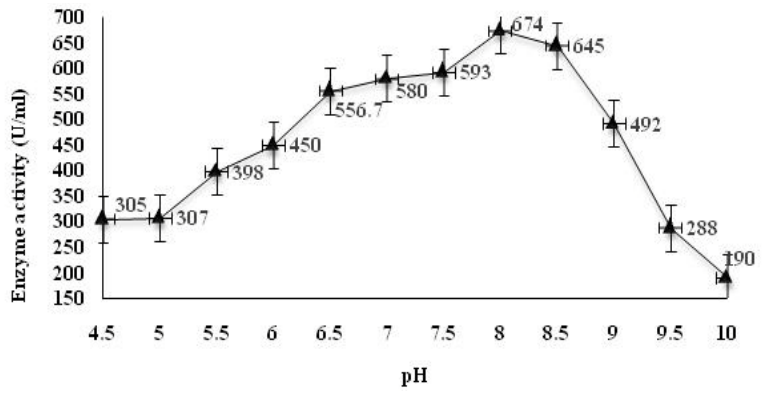

Fig. 12: Effect of $\mathrm{pH}$ on enzyme stability $\mathrm{n}=12$

\section{In vitro activity of fibrinolytic enzymes}

Blood clot inside the capillary tube was lysed by the fibrinolytic activity of the partially purified enzyme (fig. 13) within $15 \mathrm{~min}$ and no lysis was observed in control (fig. 14).

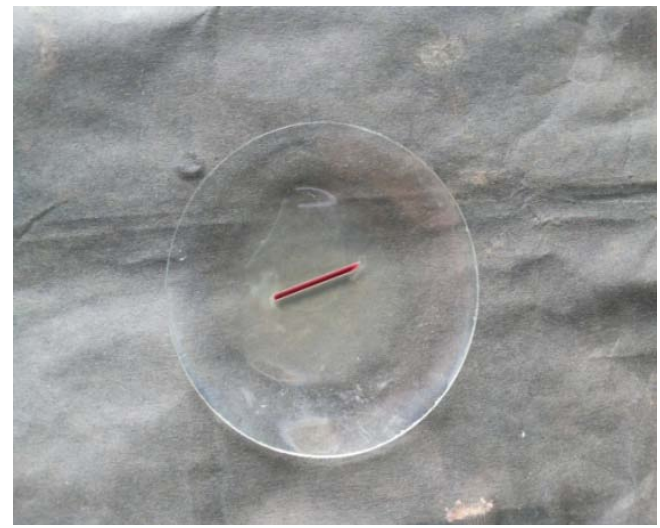

Fig. 14: Control-showing no fibrinolysis 


\section{DISCUSSION}

A fibrinolytic enzyme such as urokinase and streptokinase are very costly and can be used through intravenous administration. The result shows that the best nitrogen source for the fibrinolytic enzyme production by Aspergillus carbonarius S-CSR-0007 was casein. Several investigators studied the effect of different nitrogen sources on enzyme production. Marine Pseudomonas strain 1452, produces extracellular protease by using casein as nitrogen and carbon source [14]. Most of the higher fungi prefer organic and ammoniacal nitrogen sources than inorganic nitrogen sources [15]. The fibrinolytic enzyme from Ganoderma lucidum showed maximum fibrinolytic enzyme production with peptone as the nitrogen source [16]. In the future, we can concentrate on purification of the enzyme from fungus.

Optimum enzyme activity of enzyme production in this study was seen at $\mathrm{pH}$ 5.0, Schizophyllum commune BL23 and in Serratia marcescens [9] showed maximum enzyme production at $\mathrm{pH}$ 6.0. Cordyceps militaris showed maximum enzyme production at $\mathrm{pH} 7.0$ [17]. The optimum temperature for the enzyme production in this study was at $40^{\circ} \mathrm{C}$ which was relatively high compared to previous reports in Cordyceps militaris, Schizophyllum commune BL23, and Serratia marcescens which were $25^{\circ} \mathrm{C}, 32^{\circ} \mathrm{C}$ and $35^{\circ} \mathrm{C}$ respectively.

Ammonium sulphate salt is mostly used in precipitation process due to its low cost and high solubility, compared to other solvents and there is no effect on $\mathrm{pH}$ and temperature by this salt [18]. Based on the result, the crude enzyme shows very low enzyme activity at $20-60 \%$ ammonium sulphate saturation, indicated that the protein did not tend to aggregate and salt out of culture solution due to low ammonium sulphate concentration. However, the fibrinolytic activity increases at $80 \%$ of ammonium sulphate concentration. This indicated that the fibrinolytic enzyme precipitated at $80 \%$ ammonium sulphate concentration gave the highest enzyme activity of $1200 \mathrm{U} / \mathrm{ml}$. When compared to the crude enzyme, the enzyme activity increased more than two times with $80 \%$ ammonium sulphate saturation.

Aspergillus carbonarius S-CSR-0007 showed maximum enzyme activity at $45^{\circ} \mathrm{C}$. With the increase in temperature enzyme activity increases until $45^{\circ} \mathrm{C}$ and enzyme activity declined suddenly after 45 ${ }^{\circ} \mathrm{C}$. This is due to the velocity of enzymatic reaction increases with the increase in temperature within limited range because of increase of kinetic energy of molecule until it reach to the degree of maximum reaction velocity, but the increase of temperature at ranged which lead to disruption of the three-dimensional structure of the enzyme and then decreases its velocity [19]. This result agrees with the fact that the influence of temperature on fibrinolytic activity from Rhizopus chinensis 12 with an optimum activity was 45 ${ }^{\circ} \mathrm{C}$ [20], from Streptomyces sp. CS684 [21] and with Streptomyces sp., showed optimum enzyme activity $45{ }^{\circ} \mathrm{C}$ [22]. The optimum temperature for fibrinolytic enzyme was $40^{\circ} \mathrm{C}[2]$.

Aspergillus carbonarius S-CSR-0007 showed maximum enzyme activity at $\mathrm{pH}$ 7.0. This result agrees with a study on Bacillus lichniformis $\mathrm{B} 4$ with an optimum $\mathrm{pH}$ for maximum enzyme activity at 7.0 [8]. The fibrinolytic enzyme from Cordyceps militaris shows maximum enzyme activity at $\mathrm{pH}$ 7.0-8.0 [17] and Rhyzopus chinensis 12 showed optimum $\mathrm{pH} 7.6$ [20].

The enzyme was stable at $40-50{ }^{\circ} \mathrm{C}$ and rapid decrease in temperature observed above $50^{\circ} \mathrm{C}$, fibrinolytic enzyme from Tricholoma saponaceum and Armilleriella mellea was stable at $55^{\circ} \mathrm{C}$. Enzyme from Rhyzopus chinensis 12 showed stability at 6.8-8.8 [20]. However, an enzyme from Aspergillus carbonarius S-CSR-0007 shows higher stability when compared to others previous reports $[20,23,24,25]$. The fibrinolytic activity in Flammulina valutipes was inactivated completely at $55^{\circ} \mathrm{C}$ within $15 \mathrm{~min}$ [26]. Some previous studies showed that the fibrinolytic enzyme was relatively stable at a temperature lower than $40{ }^{\circ} \mathrm{C}$ and lost all initial activity after $10 \mathrm{~min}$ at $60^{\circ} \mathrm{C}$ [27]. The fibrinolytic enzyme from the other organisms was stable in $\mathrm{pH}$ range of 7.0-9.0 [24 26, 28]. Enzyme from Streptomyces sp. showed max enzyme stability only at 37 ${ }^{\circ} \mathrm{C}$ and at $45^{\circ} \mathrm{C}$ to $55{ }^{\circ} \mathrm{C}$ the enzyme lost its $60 \%$ activity. So this enzyme is superior among fibrinolytic enzyme.

It showed lysis of the blood clot by the enzyme within $15 \mathrm{~min}$, and from this, it is proved as a promising fibrinolytic agent, and fibrinolytic activity can be further improved by purification.

\section{CONCLUSION}

The goal of this study is to produce, purify and characterize fibrinolytic enzyme from fungal species. This study concludes that Aspergillus carbonarius S-CSR-0007 has the capacity to produce highly thermostable high $\mathrm{pH}$ stable fibrinolytic enzyme which could have broad applications in many industries. However, further work on purification and the molecular basis of the thermostable and high $\mathrm{pH}$ stable capacity of the enzyme from Aspergillus carbonarius S-CSR0007. In future, it can be an alternative cultivation system for microbial products which are costly because fungi have been utilized in solid state fermentation [29]. This enzyme showed high blood clot lysis activity, which may be a good candidate in the pharmaceutical industry.

Intravascular thrombosis is one of the main causes of CVD in human. In the present study, Aspergillus carbonarius S-CSR-0007 has been studied for the optimal production of fibrinolytic protease. Optimization of various parameters for enzyme production was carried out. Optimum $\mathrm{pH}$ for the enzyme production was seen at $\mathrm{pH}$ 5.0. The optimum temperature for the enzyme production was at 40 ${ }^{\circ} \mathrm{C}$. Aspergillus carbonarius S-CSR-0007 showed maximum enzyme activity at $\mathrm{pH} 7.0$ and at a temperature of $45^{\circ} \mathrm{C}$. The enzyme was stable at $40-50{ }^{\circ} \mathrm{C}$ and rapid decrease in temperature observed above $50{ }^{\circ} \mathrm{C}$, The partial purification of the enzyme was carried out by ammonium sulphate precipitation method and dialysis. An in vitro clot lysis assay was performed using the partially purified enzyme. The enzyme showed fibrinolytic activity within $15 \mathrm{~min}$.

\section{CONFLICTS OF INTERESTS}

The authors declare no conflict of interest.

\section{REFERENCES}

1. Mihara H. Fibrinolytic enzymes extracted from the earthworm Lumbricus rubellus: a possible thrombolytic agent. J Phys Soc Jpn 1991;53:231-43.

2. Wang SL, Chen HJ, Liang TW, Lin YD. A novel nattokinase produced by Pseudomonas sp. TKU015 using shrimp shells as substrate. Process Biochem 2009;44:70-6.

3. Dubey R, Kumar J, Agrawala D, Char T, Pusp P. Isolation, production, purification, assay and characterization of the fibrinolytic enzyme (Nattokinase, Streptokinase and Urokinase) from bacterial sources. Afr J Biotechnol 2011;10:1408-20.

4. Peng Y, Yang X, Zhang Y. Microbial fibrinolytic enzymes: an overview of the source, production, properties, and thrombolytic activity in vivo. Appl Microbiol Biotechnol 2005;69:126-32.

5. Cesarman-Maus G, Hajjar KA. Molecular mechanisms of fibrinolysis. Br J Haematol 2005;129:307-21.

6. EI-Aassar SA, EI-Badry HM, Abdel-Fattah AF. The biosynthesis of proteases with fibrinolytic activity in immobilized cultures of Penicillium chrysogenum H9. Appl Microbiol Biotechnol 1990;33:26-30.

7. Lowry $\mathrm{OH}$, Rosebrough NJ, Farr AL, Randall RJ. Protein measurement with the folin phenol reagent. J Biol Chem 1951;193:265-75.

8. Al-Juamily EF, Al-Zaidy BH. Optimization conditions of production fibrinolytic enzyme from Bacillus lichniformis B4 local isolate. Br J Pharmacol Toxicol 2012;3:289-95.

9. Mohanakumar A. Production and characterization of serratiopeptidase enzyme from Serratia marcescens. Int J Biol 2011;3:39-51.

10. Borah D, Yadav RNS, Sangra A, Shahin L, Chaubey AK. Production, purification, and characterization of nattokinase from Bacillus subtilis isolated from tea garden soil samples of Dibrugarh, Assam. Asian J Pharm Clin Res 2012;5:124-5.

11. Yin LJ, Lin HH, Jiang ST. Bioproperties of potent nattokinase from Bacillus subtilis YJ1. J Agric Food Chemi 2010;58:5737-42.

12. Raju EVN, Divakar G. Non-recombinant mutagenesis of bacillus cereus for fibrinolytic protease production. World J Pharm Pharm Sci 2013;2:6189-201.

13. Sanusi NA, Jamaluddin H. Purification of a fibrinolytic enzyme from Bacillus Sp. isolated from Budu. J Teknol 2012;59:63-8.

14. Makino K, Koshikava T, Nishithara T, Ichikawa T, Kondo M. Studies on protease from marine bacteria. Isolation of marine 
Pseudomonas sp. 145-2 and purification of protease. Microbios 1981;31:103-12.

15. Lee BC, Bae JT, Pyo HB, Choe TB, Kim SW, Hwang HJ, et al Submerged culture conditions for the production of mycelial biomass exopolysaccharides by the edible Basidiomycete Grifola frondosa. Enzyme Microb Technol 2004;35:369-76.

16. Kumaran S, Jagadish LK, Palani P, Chellaram C, Anand TP, Kaviyarasan V. Growth optimization conditions for the production of the fibrinolytic enzyme from Ganoderma lucidum. J Ecobiotechnol 2010;2:11-5.

17. Kim SA, Son HJ, Kim KK, Park HC, Lee SM, Cho BW, et al. Characterisation and production of thermostable and acid stable extracellular fibrinolytic enzyme from Cordyceps millitaris. Int J Indust Entamol 2011;22:83-93.

18. Whittaker JR. The principle of enzymology for the food science. Marcel Dekker INC., New York; 1972.

19. Segel IH. Biochemical calculations. 2nd edition. John and Sons. Inc. New York; 1976.

20. Xiao-Lan L, Lian-Xiang D, Fu-Ping L, Xi-Qun Z, Jing X. Purification and characterization of a novel fibrinolytic enzyme from Rhizopus chinensis 12. Appl Microbiol Biotechnol 2005;67:209-14.

21. Simkhada JR, Mander P, Cho SS, Yoo JC. A novel fibrinolytic protease from Streptomyces sp. CS684. Process Biochem 2010;45:88-93

22. Abdel-Naby MA, EI-Diwani AI, Shaker HM, Ismail AMS. Production and properties of the fibrinolytic enzyme from Streptomyces sp. NRC 411. World J Microbiol Biotechnol 1992;8:267-9.
23. Kim JH, Kim YS. A fibrinolytic metalloprotease from the fruiting bodies of an edible mushroom, Armillariella mellea. Biosci Biotechnol Biochem 1999;63:2130-6.

24. Kim J, Sapkota K, Park S, Choi B, Kim S, Hiep NT, et al. A fibrinolytic enzyme from the medicinal mushroom Cordyceps militaris. J Microbiol 2006;44:622-31.

25. Pandee P, Dissara Y. Production and properties of a fibrinolytic enzyme by Schizophyllum commune BL23. Songklanakarin J Sci Technol 2008;30:447-53.

26. Choi HS, Shin HH. Purification and characterization of a cysteine protease from Pleurotus ostreatus. Biosci Biotechnol Biochem 1998;62:1416-8.

27. Chang C, Fan M, Kuo F, Sung H. Potent fibrinolytic enzyme from a mutant of Bacillus subtilis IMR-NK. J Agric Food Chem 2000;48:3210-6.

28. Kim JH, Kim YS. Characterization of a metalloenzyme from a wild mushroom, Tricholoma saponaceum. Biosci Biotechnol Biochem 2001;65:356-62.

29. Lonsane BK, Saucedo-Castaneda G, Raimbault M, Roussos S, Viniegra-Gonzalez G, Ghildyal NP, et al. Scale-up strategies for solid state fermentation systems. Process Biochem 1992;27:259-73.

\section{How to cite this article}

- $\quad$ Afini AVM, Sooraj S Nath, Smitha KV, Kunhi AAM. Production and partial characterization of fibrinolytic enzyme from a soil isolate Aspergillus carbonarius S-CSR-0007. Int J Pharm Pharm Sci 2016;8(12):142-148. 